\title{
Intestinal Protozoa Infections and Associated Risk Factors in Rural Community of Samosir Island Indonesia
}

\author{
Hemma Yulfi ${ }^{1}$, Dewi Masyithah Darlan ${ }^{2}$, Toni Wandra ${ }^{3}$ Ivan Elisabeth Purba ${ }^{4}$, Yunita Purba ${ }^{5}$, John M. Saragih ${ }^{6}$, \\ Akira Ito $^{7}$ \\ ${ }^{1,2}$ Department of Parasitology, Medical Faculty of Universitas Sumatera Utara, Indonesia \\ hemmayulfi@gmail.com \\ dmasyithah57@gmail.com \\ ${ }^{3}$ University of Sari Mutiara Indonesia, Indonesia \\ tony_wdr2009@yahoo.com \\ ${ }^{6}$ National Institute of Health Research and Development, Ministry of Health, Indonesia \\ johnmastersaragih@yahoo.com \\ ${ }^{7}$ Department of Parasitology, Asahikawa Medical University, japan \\ akiraitolashahikawa-med.ac.jp
}

\begin{abstract}
Intestinal protozoa infections are still a major health concern in tropical countries and considered one of neglected tropical infections. Giardia lamblia as one of the human protozoa can cause significant morbidity. It is associated with lack of personal hygiene and environmental sanitation, such as inadequate toilet, lack of hand washing habit, unimproved water supply, and insufficient handling of foods. Some other protozoa such as Balantidium coli and Blastocystis hominis are correlated with the farming. However, data on the prevalence and risk factors is still scarce in Indonesia, Hence, this study was aiming to determine the correlation between the risk factors and the prevalence of protozoa infections among the community in Samosir Island, the island in the centre of Lake Toba, North Sumatera, Indonesia.

This was an analytical study using cross-sectional design, conducted in 2015. Faecal samples were collected from 368 participants and then examined microscopically for qualitative analysis. Demographic data and risk factors were also collected using questionnaires, which was then analysed using computer statistical analysis program for data description and correlation.

The study found that $23.1 \%$ of faecal samples were positive for intestinal protozoa. Giardia lamblia was the most common infection (12.23\%), followed by Blastocystis spp. (4.89\%) and Entamoeba coli $(4.35 \%)$. There were also mix infections between species, each comprises around $1 \%$. Indiscriminate defecation, lack of sufficient hand washing, unprocessed drinking water, and swine farming showed strong correlation, all of which with $p$ value $<0.05$. However, there was no correlation showed with cattle farming and water source.
\end{abstract}

Keywords - intestinal protozoa, personal hygiene, sanitation, toilet, water source, swine farming, Indonesia

\section{INTRODUCTION}

Intestinal protozoa infections remain a world health burden, inflicting a vast amount of morbidity and even mortality particularly in tropical and subtropical regions. The infection is most prevalent among community where water, hygiene and sanitation facilities are insufficient, especially in highly density residential areas or in rural settings [1], [2]. Several infectious diseases caused by intestinal protozoa have been classified as neglegted tropical infections. Global data has estimated that intestinal amoebiasis caused by Entamoeba hystolytica was ranked within top five most fatal parasite-related diseases in 2003 [3], whilst the prevalence of Giardia intestinalis infection was up to $30 \%$ among low- and middle-income countries [4], [5].

Since intestinal protozoa is mainly transmitted through contaminated water, the lack of access to safe water source, unimproved hygiene and sanitation facilities are of the major contributors to the disease. The source of contamination includes excreta, both from human and animals, and other organic waste. Hence, this study was aiming to assess the prevalence of intestinal protozoa infection and its associated risk factors within the community in rural area of Samosir Island, Lake Toba Indonesia. The establishment of such data is hoped to be beneficial to recommend for control strategies and policies. 


\section{MATERIALS AND METHODS}

\section{A. Study Design and Population}

A cross-sectional study was performed in Samosir Island Indonesia in September 2015. Geographically the island is located within Lake Toba (North Sumatera) between $2^{\circ} 21^{\prime} 38^{\prime \prime}-2^{\circ} 49^{\prime} 48^{\prime \prime}$ $\mathrm{N}$ latitude and $98^{\circ} 24^{\prime} 00^{\prime \prime}-99^{\circ} 01^{\prime} 48^{\prime \prime} \mathrm{E}$ longitude. The altitude is $904 \mathrm{~m}-2,157 \mathrm{~m}$ above sea level with an average annual temperature ranging between $14.6-32.9^{\circ} \mathrm{C}$ and a humidity rate of $85.04 \%$. There were approximately 123,789 inhabitants in the district; almost $25 \%$ of which resides in the district's capital. Over $70 \%$ of the labour working as farmers, the rest were in tourism and government sectors [6], [7].

\section{B. Sampling and Data Collection}

A consecutive sampling, regardless of age or gender, was performed in community health centres of three villages from two subdistricts: Simanindo and Ronggur Nihuta. The selection of villages was made based on approval and willingness to participate by the head of municipals and community members. Two of the three villages were located at the lower land by the lake shore, whose utilized lake for their main water source. The other village was located in the higher land, which relied on the rain for its water source. This is due to the distant access to the lake and the rare availability of water springs and water wells.

Villagers were required to provide a fresh morning stool sample to assess the presence of intestinal protozoa. Wide mouth screw capped plastic containers were distributed to community in selected villages prior to data collection, along with the instructions on collecting and handing over the specimen. Villagers who turned up with stool samples to the study sites the following day were then included in the study. After obtaining consent, respondents were interviewed on demography and risk factors by trained personnel. Each sample was processed and examined microscopically twice for the presence of parasites by using lugol and normal saline. Participants with positive results were then treated with metronidazole. All of the participants were also generally examined by physicians and treated accordingly.

\section{Statistical Analysis}

Initially parasite prevalence was assessed descriptively by using Microsoft Excel 2007. Risk factors were identified using multivariate analysis. Associations between each variable were examined using Pearson's Chi-square on proportion. An odds ratio was estimated for categorical variables. $P$ values less than 0.05 were considered statistically significant. SPSS software (Statistical Package for the Social Sciences) for windows version 15 (SPSS, IBM, Chicago, USA) was employed for statistical analysis.

\section{RESULTS}

\section{A. Descriptive Analysis and Prevalence of Intestinal Protozoa}

The study included a total of 368 villagers, consisted of 112 males (30.4\%) and 256 females $(69.64 \%)$. The age was ranging between 1 and 80 years old, which were categorized into two age groups (Table 1). About $23.10 \%$ (85) of the participants were infected with at least one intestinal protozoa. Giardia intestinalis was the most prevalent species (12.23\%; 45) followed by Blastocystis spp. and Entamoeba coli whose prevalence rates were $4.89 \%$ (18) and $4.35 \%$ (16) respectively (Table II).

TABLE I

PREVALENCE OF INTESTNAL PROTOZOA INFECTIONS B Y GENDER AND AGE GROUPS IN SAMOSIR ISLAND INDONESIA ( $\mathrm{N}=368$ )

\begin{tabular}{|l|c|c|c|c|c|}
\hline \multirow{2}{*}{$\begin{array}{c}\text { Charater- } \\
\text { istics }\end{array}$} & \multicolumn{3}{|c|}{$\begin{array}{c}\text { Intestinal Protozoa } \\
\text { Infection }\end{array}$} & \multirow{2}{*}{$\begin{array}{c}\text { OR } \\
(\mathbf{9 5 \%} \text { CI) }\end{array}$} & \multirow{2}{*}{$\boldsymbol{p}$ value } \\
\cline { 2 - 4 } & $\mathbf{n}$ & Positive & $\mathbf{\%}$ & & \\
\hline Gender & & & & & \\
\hline Male & 112 & 24 & 21.43 & $\begin{array}{c}0.87 \\
(0.51-1.49)\end{array}$ & 0.615 \\
\hline Female & 256 & 61 & 23.83 & & \\
\hline Age & & & & & 0.962 \\
\hline$\leq 15$ & 159 & 45 & 23.20 & $\begin{array}{c}1.01 \\
(0.62-1.64)\end{array}$ & 0.962 \\
\hline$>15$ & 209 & 40 & 22.99 & & \\
\hline
\end{tabular}

TABLE II

DISTRIBUTION OF INTESTINAL PROTOZOA INFECTIONS BY SPECIES IN SAMOSIR ISLAND INDONESIA ( $\mathrm{N}=368$ )

\begin{tabular}{|l|c|c|}
\hline \multicolumn{1}{|c|}{ Protozoa Species } & n & \% \\
\hline No infection & 283 & 76.90 \\
\hline Giardia intestinalis & 45 & 12.23 \\
\hline Blastocystis spp. & 18 & 4.89 \\
\hline Entamoeba coli & 16 & 4.35 \\
\hline Giardia intestinalis + Entamoba coli & 4 & 1.09 \\
\hline Entamoeba coli + Blastocystis spp. & 2 & 0.54 \\
\hline
\end{tabular}


TABLE III

Distribution OF INTESTINAL PROTOZOA AMONG AGE GROUPS IN SAMOSIR ISLAND INDONESIA

\begin{tabular}{|l|c|c|c|c|}
\hline \multirow{2}{*}{ Intestinal Protozoa Infections } & \multicolumn{2}{|c|}{$\leq \mathbf{1 5}$} & \multicolumn{2}{c|}{$>\mathbf{1 5}$} \\
\cline { 2 - 5 } & $\mathbf{n}$ & $\mathbf{\%}$ & $\mathbf{n}$ & $\mathbf{\%}$ \\
\hline Giardia intestinalis & 25 & 55.56 & 20 & 50 \\
\hline Blastocystis spp. & 10 & 22.22 & 11 & 27.5 \\
\hline Entamoeba coli & 7 & 15.56 & 6 & 15 \\
\hline G intestinalis + E coli & 2 & 4.44 & 2 & 5 \\
\hline E coli + Blastocystis spp. & 1 & 2.22 & 1 & 2.5 \\
\hline Total & 45 & 100 & 40 & 100 \\
\hline
\end{tabular}

\section{B. Intestinal Protozoa Infections and Risk Factors}

Risk factors associated with intestinal protozoa infections in relation to personal hygiene and environmental sanitation were assessed by multivariate analysis. The data on risk factors are summarized in Table IV. Five out of 7 risk factors observed showed significant relationship with the infection $(p<0.05)$.

TABLE IV

MULTIVARIATE ANALYSIS OF RISK FACTORS ASSOCIATED WITH INTESTINAL PROTOZOA INFECTIONS IN SAMOSIR ISLAND INDONESIA (N=368)

\begin{tabular}{|c|c|c|c|c|c|}
\hline \multirow[t]{2}{*}{ Risk Factors } & \multicolumn{3}{|c|}{$\begin{array}{c}\text { Intestinal Protozoa } \\
\text { Infection }\end{array}$} & \multirow{2}{*}{$\begin{array}{c}\text { OR } \\
(95 \% \mathrm{CI})\end{array}$} & \multirow[t]{2}{*}{$p$ value } \\
\hline & $\mathbf{n}$ & Positi-ve & $\%$ & & \\
\hline \multicolumn{6}{|l|}{ Toilet } \\
\hline Inadequate & 192 & 70 & 82.4 & \multirow{2}{*}{$\begin{array}{c}6.23 \\
(3.40-11.42) \\
\end{array}$} & \multirow{2}{*}{$<0.0001 *$} \\
\hline Adequate & 178 & 15 & 17.6 & & \\
\hline \multicolumn{6}{|l|}{$\begin{array}{l}\text { Hand washing } \\
\text { before eating }\end{array}$} \\
\hline Insufficient & 159 & 55 & 34.6 & 2.27 & \multirow{2}{*}{$0.0001 *$} \\
\hline Sufficient & 209 & 30 & 14.3 & $(1.38-3.74)$ & \\
\hline \multicolumn{6}{|l|}{\begin{tabular}{|l|} 
Hands washing \\
after defecating
\end{tabular}} \\
\hline Insufficient & 188 & 68 & 38.2 & \multirow{2}{*}{$\begin{array}{c}5.43 \\
(3.04-9.72)\end{array}$} & \multirow{2}{*}{$<0.0001 *$} \\
\hline Sufficient & 180 & 17 & 9.4 & & \\
\hline \multicolumn{6}{|l|}{$\begin{array}{l}\text { Household water } \\
\text { source }\end{array}$} \\
\hline $\begin{array}{l}\text { Open (lake, rain } \\
\text { pool) }\end{array}$ & 316 & 75 & 23.7 & \multirow{2}{*}{$\begin{array}{c}1.32 \\
(0.63-2.73)\end{array}$} & \multirow{2}{*}{0.476} \\
\hline $\begin{array}{l}\text { Well/water } \\
\text { spring/boorholes }\end{array}$ & 52 & 10 & 19.2 & & \\
\hline \multicolumn{6}{|l|}{ Drinking water } \\
\hline Unprocessed & 96 & 55 & & \multirow{2}{*}{$\begin{array}{c}10.82 \\
(6.22-18.84)\end{array}$} & \multirow{2}{*}{$<0.0001 *$} \\
\hline Processed & 272 & 30 & & & \\
\hline \multicolumn{6}{|l|}{ Swine farming } \\
\hline Yes & 136 & 47 & 34.6 & \multirow{2}{*}{$\begin{array}{c}2.69 \\
(1.64-4.43) \\
\end{array}$} & \multirow{2}{*}{$0.0001 *$} \\
\hline No & 232 & 38 & 16.4 & & \\
\hline \multicolumn{6}{|l|}{ Cattle farming } \\
\hline Yes & 142 & 35 & 24.6 & \multirow{2}{*}{$\begin{array}{c}1.15 \\
(0.70-1.89)\end{array}$} & \multirow{2}{*}{0.58} \\
\hline No & 226 & 50 & 22.1 & & \\
\hline
\end{tabular}

*Significant correlation

\section{DISCUSSION}

The study found a moderate prevalence of intestinal protozoa in the population. Giardia intestinalis was the most frequent, followed by Blastocystis spp. and Entamoeba coli. Similar prevalence of Giardia intestinalis was also found in other studies [1], [8]. These findings were relevant with the global data that revealed Giardia intestinalis as the most common protozoal infection in humans associated with drinking water [9], [10]. However, different studies in different part of the globe have reported variable findings. The predominant prevalent protozoa seems to vary depends on settings and population [1], [2], [11][15]. Blastocystis spp. was found in low prevalence in this study. However, Blastocystis spp. is recently considered an under-reported parasite. Other study that employed PCR revealed much higher prevalence on this parasite [16].

The study found no difference in relation to gender and age on the prevalence of intestinal protozoa. This is in line with other findings [16]-[18] and indicated that intestinal protozoa infection may or may not correlate to gender or age. Males and females of any age have equal opportunity to get infected, depends on the risk factors available in the setting. The differences might appear in the outcome of the infection, in which children and vulnerable group would increase susceptibility to the infection, thus suffer from more severe manifestation [5].

Giardia intestinalis is known as pathogens whose infection can lead to severe morbidity and mortality, whilst the role of other protozoa found in this study, i.e. Blastocystis spp. and Entamoeba coli, remains uncertain [5], [19]. However, the presence of these protozoa might have indicated the sanitary level in the study population.

It has long been established that enteric protozoa infection is associated with hygiene behaviour and environmental sanitation. This study found plausible correlation between the infection with defecation habit, lack of hand-washing habit, untreated drinking water, and possession of swine farming. Indiscriminate defecation plays an important role in the occurrence of infection. Unimproved latrine will increase the risk of human exposure to the infective stage of the parasites. The cysts can be transferred by vectors or pests to contaminate foods and water. Patients or carriers, both humans and animals, who defecate in open field or in inadequate toilet (e.g. pit latrine) will 
release parasites that can be transmitted to other people by the means of mechanical vectors, wind or flood water [5].

Humans are susceptible to infection with numerous species of intestinal protozoa which also have zoonotic potential [19]. The study suggested strong correlation between the possession of swine farming with the infection. This finding was in agreement with other study, in which Balantidium coli being the most prevalent protozoa in the pig farms [12]. Most of the swine and cattle farms in this study population were managed traditionally. In such farming, the farmers possess humble infrastructure, and animals are mostly targeted for limited market. Upon observation, we found that most of the pig farmers keep their animals around the house; the semi-confined or unconfined pigs were wandering in the house yards. The adjacent living between man and animals will eventually increase the risk of infection as both parties can share the same parasites.

Interestingly, the correlation was not shown between cattle farming and the infection. This might be due to the nature of cattle farming in the study population. Unlike pigs, cattle were only kept in the house perimeter at nights. During the day farmers released the ungulates to feed in the grass fields, which were usually distant from houses.

In relation to washing hand habit, the study found strong correlation with the infection $(p<0.05)$. Washing hands regularly with soap and water protects man from getting infected with the parasites [20], although other studies reported otherwise [1], [21]. Some records have documented that children engaged with washing habit had lower levels of medical leave from school [22], [23]. In Indonesia, since a lot of people eat with bare hands particularly in rural community, hand-washing is mostly practiced prior to eat than after defecation. Moreover, most toilets in Indonesia are wet toilet, in which it allows people to wash after defecating instead of a mere tissue paper. However, the use of soap along with water is not generally practiced.

The hand-washing habit is also of paramount important among mothers and food handlers. A study in Bangladesh has documented that washing hands prior to preparing food has significantly reduced diarrhoea in children even without using soap [24]. Meanwhile a more recent study in Indonesia had an in-line report that mothers lacked hand-washing and food hygiene practice increased the risk of diarrhoea in children under 2 years old [25].

People in the lower land are benefited from the lake. They utilized lake as the main water source for domestic needs, i.e. drinking and washing.

People in the island also used the lake as recreational water. Children swam in the lake as part of playing and earning. Some children swam in the harbour to attract tourists; they would dive to catch coins thrown in to the lake by the visitors. A recent study revealed that swimming activity might increases the risk of ingestion of water [26]. Moreover, there is a record of recreational water being source of transmission of infection, with parasites as the leading cause both in treated and untreated water environment [27].

On the other hand, people in the higher land relied mostly on the rain to provide them with water all year long. In contrast to general observations, during rainy seasons when water is abundant, the prevalence of water-borne diseases in this particular area might be lower compared to the other season. In dry seasons the risk to infection increases as people would use any water compound available, including communal ponds that are used publicly, including by wild animals (Fig. 1).

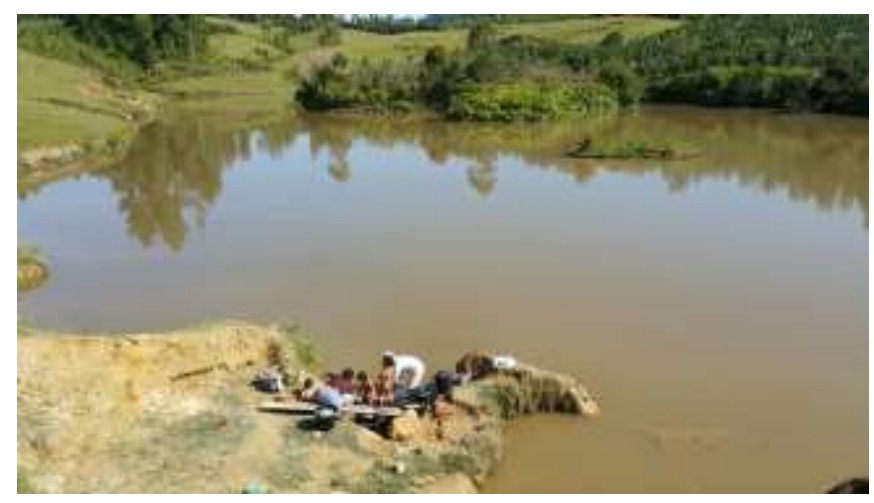

Fig. 1 Water compound in the higher land in Samosir Island used by community for domestic purposes

We considered water spring, well and boreholes safer water sources compared to open sources like lake and ponds. Nevertheless, there was no differences found between both categories ( $p=$ 0.476). Water springs and wells are safe if managed 
adequately. Contamination less occurs to the sources that are well protected, e.g. by keeping a good distance to sewage or septic tanks and other source of pathogen contamination, and using water treatment like chlorine if required.

Furthermore, drinking water obtained from any source needs to be processed before being consumed. The present study found that unprocessed drinking water increased the risk of infection by 10.82 times (95\% CI $=6.22-18.84)$. The water could possibly be contaminated with protozoa, raising the susceptibility to the water-borne infections [2], [10].

Despite all the findings, this study needs to acknowledge some limitations. Firstly, the direct smear examination method employed in this study only required small amount of sample, which might have reduced the estimates of the infection. Secondly, some protozoa are not easy to identify by a mere microscopic examination. And lastly, the cross-sectional survey only reflects one point in time, i.e. the rainy season. A similar study conducted in dry season may reveal different results.

\section{CONCLUSIONS}

Moderate prevalence of intestinal protozoa infection was observed among the rural and remote community of Samosir Island Indonesia. Risk factors associated with the infection should be addressed effectively. Health policies must also focus on the provision of safe water supply and health education to promote health and hygiene awareness.

\section{CONFLICT OF INTERESTS}

The authors declare that there were no competing interests in the study.

\section{ACKNOWLEDGMENT}

We would like to address our gratitude to all participants who cooperated in this study, all caretakers and Samosir Island health officers for the assistance and contribution in collecting the data. We are also thankful to University of Sari Mutiara Medan, North Sumatra, for its support to this research.

\section{REFERENCES}

[1] A. Abossie, M. Seid. "Assessment of the prevalence of intestinal parasitosis and associated risk factors among primary school children in Chencha town, Southern Ethiopia". BMC Public Health, vol. 14, pp. 166,2016

[2] S. Mtapuri-Zinyowera, V. Ruhanya, N. Mitzi, et al. "Human parasitic protozoa in drinking water sources in rural Zimbabwe and their links to HIV infection", GERMS, vol. 4(4), pp. 88, 2014

[3] S. L. Stanley Jr. "Amoebiasis". Lancet., vol. 361, pp. 1025-34, 2003

[4] T. Vos, R. M. Barber, B. Bell, A. Bertozzi-Villa, S. Biryukov, I. Bolliger, et al. "Global, regional, and national incidence, prevalence, and years lived with disability for 301 acute and chronic diseases and injuries in 188 countries, 1990-2013: a systematic analysis for the Global Burden of Disease study 2013”. Lancet, vol. 386, pp.743-800, 2015

[5] S. M. Fletcher, D. Stark, J. Harkness, J. Ellis. "Enteric protozoa in the developed world: a public health perspective". Clin Microbial Rev, vol. 25, pp. 420-49, 2012

[6] The Central Bureau of Statistics of Samosir Regency. District Statistics of Samosir Regency 2016. BPS-Statitics of Samosir Regency, Samosir, Indonesia, 2016

[7] BPS-Statistics of Samosir Regency. "Samosir in Figures 2016", BPSStatitics of Samosir Regency, Samosir, Indonesia, 2016

[8] K. G. Girotto, D. F. Grama, M. J. Cunha, et al. "Prevalence and Risk Factors for Intestinal Protozoa Infection in Elderly Residents at Long Term Residency Institutions in Southeastern Brazil”. Rev. Inst. Med. Trop. SaoPaulo, vol 55(1), pp. 19-24, 2013

[9] J. Hawrelak. "Giardiasis: Patophysiology and Management". Altern Med Rev, vol. 8(2), pp. 129-142, 2003

[10] S. Baldursson, P. Karanis P. "Waterborne transmission of protozoan parasites: review of worldwide outbreaks - an update 2004-2010". Water Res, vol. 45, pp. 6603-6614, 2011

[11] S. Erisman, S. Diabouga, P. Odermatt, et al. "Prevalence of intestinal parasitic infections and associated risk factors among schoolchildren in the Plateau Central and Centre-Ouest regions of Burkina Faso". Parasites \& Vectors, vol. 9(554), 2016

[12] A. S. Barbosa, O. M. P. Bartos, 1. V. Dib, et al. "Gastrointestinal parasites of swine raised in different management systems in the State of Rio de Janeiro, Brazil”. Presq. Vet. Bras, vol 35(12), pp. 941-946, Des. 2015

[13] L. S. Galgamuwa, D. Iddawela, and S. D. Dharmaratne. "Intestinal protozoa infections, associated risk factors and clinical features among children in low-income tea plantation community in Sri Lanka". Int J Community Med Public Health, vol. 3(9), pp. 2452-2458, Sept. 2016

[14] M. Sharif, M., A. Daryani, F. Asgarian, F. and M. Nasrolahei. "Intestinal parasitic infections among intellectual disability children in rehabilitation centers of northern Iran". Res Dev Disabil, vol. 31, pp. 924-928, 2010

[15] R. B. Sah, I. S. Prudel, R. Baral, N. Jha, and P. K. Pokharel. "A Study of Prevalence of Intestinal Protozoan Infections and Associated Risk Factors among the School Children of Itahari Eastern Region of Nepal". Journal of Chitwan Medical College, vol. 3(3), pp. 32-36, 2013

[16] M. Osman, D. El Safadi, A. Cian, et al. "Prevalence and Risk Factors for Intestinal Protozoan Infections with Cryptosporidium, Giardia, Blastocystis and Dientamoeba among Schoolchildren in Tripoli, Lebanon, PLoS Negl Trop Dis, vol. 10(3), pp. e0004496, March 2016

[17] R. Ngui, S. Ishak, S. K. Chow, R. Mahmud, Y. A. Lim. "Prevalence and Risk Factors of Intestinal Parasitism in Rural and Remote West Malaysia”. PloS Negl Trop Dis, vol 5(3), March 2011

[18] B. Matthys, M. Bobieva, G. Karimova, A. Mengilboeva, V. JeanRichard et al. "Prevalence and risk factors of helminths and intestinal protozoa infections among children from primary schools in western Tajikistan", Parasites \& Vectors, vol. 4(195), 2011

[19] R. C. A Thompson and A. Smith. "Zoonotic Enteric Protozoa", Veterinary Parasitology, vol. 182, pp. 70-78, 2011

[20] M. Wordemann, K. Polman, L. T. M. Heredia, R. J. Diaz, A. M. C. Madurga, F. A. N. Fernandez, et al. "Prevalence and risk factors of intestinal parasites in Cuban children". Trop Med Int Health, vol. 11, pp. 1813-1820, 2006

[21] J. Siwila and A. Olsen. "Risk Factors for Infection with Soil Transmitted Helminths, Cryptosporidium spp., and Giardia duodenalis in Children Enrolled in Preschool in Kafue District, Zambia", Epidemiology Research International, vol. 2015, 2015 
[22] C. Lopez-Quintero, P. Freeman, and Y. Neumark, "Hand washing among school children in Bogota, Colombia". Am J Public Health, vol. 99(1), pp. 94-101, 2009

[23] C. H. Lau, E. E. Springston, M. W. Sohn, I. Mason, et al., "Hand hygiene instruction decreases illness-related absenteeism in elementary schools: a prospective cohort study". BMC Pediatr, vol. 12, pp. 52, 2012

[24] S. P. Luby, A. K. Halder, T. Huda, L. Unicomb, R. B, Johnston. "The effect of handwashing at recommended times with water alone and with soap on child diarrhea in rural Bangladesh: an observational study". PLoS medicine, vol. 8(6), pp. e1001052, 2011

[25] R. Agustina, T. P. Sari, S. Sastroamidjojo, et al. "Association of foodhygiene practices and diarrhea prevalence among Indonesian young children from low socioeconomic urban areas". BMC public health, vol. 13 (1), pp. 977, 2013

[26] S. Dorevitch, S. Panthi, Y. Huang. H. Li, et al., "Water ingestion during water recreation. water research", Water Res, vol. 45(5), pp. 2020-2028, 2011

[27] M. C. Hlavsa, and J.M. Brunkard, "Surveillance for waterborne disease outbreaks and other health events associated with recreational water--United States, 2007-2008'. US Department of Health and Human Services, Centers for Disease Control and Prevention, 2011 